\title{
Synthesis and Crystal Structure of the Hydrogen Bromide Salt of 1,4,7,10-Tetrakis(2-((4-methoxy)phenoxy) ethyl)-1,4,7,10-tetraazacyclododecane
}

\author{
Wei Zhao ${ }^{*}$, Yun Wang', Aijian Wang2* \\ ${ }^{1}$ School of Energy \& Power Engineering, Jiangsu University, Zhenjiang, China \\ ${ }^{2}$ School of Chemistry \& Chemical Engineering, Jiangsu University, Zhenjiang, China \\ Email: ^wajujs@ujs.edu.cn
}

How to cite this paper: Zhao, W., Wang, Y. and Wang, A.J. (2017) Synthesis and Crystal Structure of the Hydrogen Bromide Salt of 1,4,7,10-Tetrakis(2-((4-methoxy)ph enoxy)ethyl)-1,4,7,10-tetraazacyclododecane. Journal of Materials Science and Chemical Engineering, 5, 1-11.

https://doi.org/10.4236/msce.2017.510001

Received: September 20, 2017

Accepted: October 22, 2017

Published: October 25, 2017

Copyright $\odot 2017$ by authors and Scientific Research Publishing Inc. This work is licensed under the Creative Commons Attribution International License (CC BY 4.0).

http://creativecommons.org/licenses/by/4.0/

\begin{abstract}
A novel molecule tetra- $\mathrm{N}$-alkylation of cyclen (1,4,7,10-tetraazacyclododecane), 1,4,7,10-tetrakis(2-((4-methoxy)phenoxy)ethyl)-1,4,7,10-tetraazacyclododecane 1 , was synthesized and structurally characterized by the single-crystal X-ray diffraction. The crystals were obtained from ethanol by slow evaporation at room temperature and the four hydroquinone groups of the benzene ring formed a $\pi$-electron-rich cavity by $\mathrm{C}-\mathrm{H} \cdots \mathrm{Br}$ stacking interaction. The crystal belongs to the orthorhombic system, space group $\mathrm{Pbcn}$ with $\mathrm{a}=17.3174(15)$, $\mathrm{b}=12.9891(11), \mathrm{c}=19.3379(17) \AA, \alpha=\beta=\gamma=90^{\circ}, \mathrm{V}=4349.8(7) \AA^{3}, \mathrm{Z}=4$, $\mathrm{Dc}=1.304 \mathrm{~g} / \mathrm{cm}^{3}, \mathrm{C}_{44} \mathrm{H}_{61} \mathrm{BrN}_{4} \mathrm{O}_{8}, \mathrm{Mr}=853.88, \mathrm{~F}(000)=1808, \mu=1.001$ $\mathrm{mm}^{-1}$, CuKa radiation $(\lambda=0.71073), \mathrm{R}=0.0434$ and $w \mathrm{R}=0.1091$ for 5200 observed reflections with $\mathrm{I}>2 \sigma(I)$.
\end{abstract}

\section{Keywords}

Synthesis, Crystal Structure, Cyclen Derivative

\section{Introduction}

With the high abilities in recognizing specific DNA sequence and catalyzing hydrolysis of phosphate diester bonds, chemical nucleases have rapidly become an invaluable research tool in the fields of biology, bioorganic chemistry, therapy, and molecular biology [1]-[6]. Many complexes have been designed and studied. In this used ligands, cyclen with four benzyl groups, can coordinate with most mental cations or negative ion. The successful application of several cyclen 
derivative complexes for biomedical applications has stimulated interest for new cyclen-based ligands with different types of pendant arms in an attempt to find new ligands with different chemical, biological or catalytic properties [7] [8] [9] [10] [11]. Since armed cyclens have many structural and geometrical variations, they form a wide variety of metal complexes having specific sensing and signaling functions [12].

Recently, many cyclen derivatives with different types of pendant arms have been designed and reported, but only a few compounds bearing four benzyl groups. Smith C. B. and coworkers reported the preparation of the cyclen derivatives: (R)-thppc12 (L) and (S)-thph-pc12 (L'), including four benzyl or phenoxy-methyl groups, where benzyl or phenoxymethyl groups project in the same direction due to the open nature of the electron-rich cavity [13]. If, in addition to bearing a donor atom, the pendant arms also have an aromatic moiety attached to them, the possibility arises of using the coordination of the ligand to a metal ion as a way of assembling a molecular receptor with a substantial cavity.

Encouraged by these considerations, we describe herein the synthesis of a new type of cyclen-base ligand with four neutral pendent groups at $\mathrm{N}$ residuals according to Scheme 1. Herein, X-ray crystal structure determination of compound 1 is undertaken to better understand the influence of structure modifications upon overall molecular geometry and conformation.

\section{Experimental Section}

\subsection{Materials and Instruments}

All chemicals were of reagent grade and used without further purification. All aqueous solutions were prepared from deionized or distilled water. Reaction and the resultant products were monitored by thin-layer chromatography (TLC) on Merck pre-coated silica gel F254 plates with separated compounds visualized at $254 \mathrm{~nm}$ under a UV lamp. Melting point (uncorrected) was determined on a XT4 MP: apparatus (Taike Corp, Beijing, China). NMR was recorded in $\mathrm{CDCl}_{3}$ on a Varian Mercury 300 spectrometer and resonance was given in ppm $(\delta)$ relative to TMS.

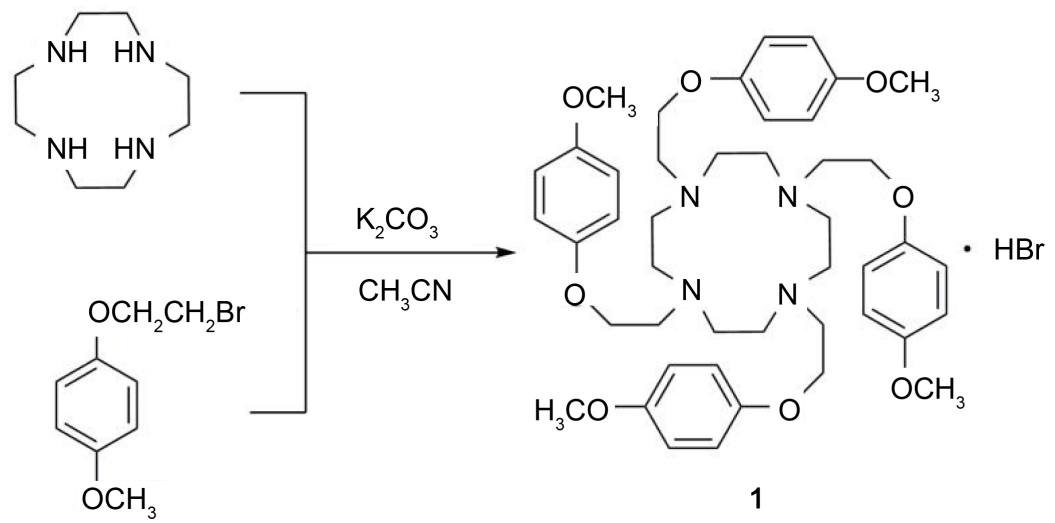

Scheme 1. Synthetic route to compound 1. 


\subsection{Synthesis of the Title Compound (1)}

Compound 1 was synthesized based on literature method (Scheme 1) [14]. To a solution of cyclen $(0.2 \mathrm{~g}, 1.16 \mathrm{mmol}), 1$-(2-bromoethoxy)-4-methoxybenzene ( $1.34 \mathrm{~g}, 5.8 \mathrm{mmol})$ in $30 \mathrm{~mL} \mathrm{CH}{ }_{3} \mathrm{CN}$ was added $\mathrm{K}_{2} \mathrm{CO}_{3}(0.83 \mathrm{~g}, 6.0 \mathrm{mmol})$. The resulting solution was heated under reflux and the progress of the reaction was monitored by TLC $\left(\mathrm{CH}_{2} \mathrm{Cl}_{2} / \mathrm{CH}_{3} \mathrm{OH}\right.$ 7:1 silica gel). After disappearance of the starting material (ca. $8 \mathrm{~h}$ ), the remaining solids were removed by filtration, and the filtrate was cooled to give compound 1, white solid, yield: $89.5 \%$. Melting point: $128^{\circ} \mathrm{C}-129^{\circ} \mathrm{C} .{ }^{1} \mathrm{H}$ NMR $\left(300 \mathrm{MHz}, \mathrm{CDCl}_{3}\right), \delta(\mathrm{ppm}): 6.79-6.69(16 \mathrm{H}$, dd, $\left.\mathrm{C}_{6} \mathrm{H}_{4}\right), 4.02\left(8 \mathrm{H}, \mathrm{s}\right.$, cyclen- $\left.\mathrm{CH}_{2} \mathrm{CH}_{2} \mathrm{O}\right), 3.75\left(12 \mathrm{H}, \mathrm{s}, \mathrm{OCH}_{3}\right), 3.27(8 \mathrm{H}, \mathrm{s}$, cyclen- $\left.\mathrm{CH}_{2} \mathrm{CH}_{2} \mathrm{O}\right), 3.13\left(16 \mathrm{H}, \mathrm{s}, \mathrm{NCH}_{2} \mathrm{CH}_{2} \mathrm{~N}\right)$.

\section{X-Ray Crystal Structure Determination}

Crystallographic characteristics and X-ray-data collection and structure refinement parameters are presented in Table 1 . Selected bond lengths are provided in Table 2. Selected bond angles are provided in Table S1. The crystal of $1(0.2 \mathrm{~mm} \times$

Table 1. Crystal data and structure refinement parameters of $\mathrm{C}_{44} \mathrm{H}_{61} \mathrm{BrN}_{4} \mathrm{O}_{8}$ (1).

\begin{tabular}{|c|c|}
\hline System, sp. gr., Z & Orthorhombic, $\mathrm{Pbcn}, 4$ \\
\hline $\mathrm{a}, \mathrm{b}, \mathrm{c} \AA$ & 17.3174(15), 12.9891(11), 19.3379(17) \\
\hline$\alpha, \beta, \gamma \operatorname{deg}$ & $90,90,90$ \\
\hline $\mathrm{V}, \AA^{3}$ & $4349.8(7)$ \\
\hline $\mathrm{D}_{\mathrm{x}} \mathrm{g} \cdot \mathrm{cm}^{-3}$ & 1.304 \\
\hline Radiation, $\lambda, \AA$ & $\mathrm{CuKa}, 0.71073$ \\
\hline$\mu, \mathrm{mm}^{-1}$ & 1.001 \\
\hline $\mathrm{T}, \mathrm{K}$ & $293(2)$ \\
\hline Sample size, $\mathrm{mm}$ & $0.2 \times 0.2 \times 0.2$ \\
\hline Diffractometer & Apex II \\
\hline Scan mode & $\omega / \varphi$ \\
\hline Absorption correction, $\mathrm{T}_{\min }, \mathrm{T}_{\max }$ & Multi-scan, $0.819,0.819$ \\
\hline$\theta_{\max }, \operatorname{deg}$ & 28.08 \\
\hline$h, k, 1$ ranges & $-22 \leq \mathrm{h} \leq 22,-16 \leq \mathrm{k} \leq 6,-25 \leq 1 \leq 24$ \\
\hline $\begin{array}{l}\text { Number of reflections: measured/unique (N1), } \\
\text { Rint/with I > 2o(I) (N2) }\end{array}$ & $24759 / 5200,0.0434 / 2982$ \\
\hline Refinement method & Full-matrix least-squares on $\mathrm{F}^{2}$ \\
\hline Number of refined parameters & 260 \\
\hline $\mathrm{R} 1 / \mathrm{wR} 2$ relative to $\mathrm{N} 1$ & $0.0434 / 0.1091$ \\
\hline $\mathrm{R} 1 / \mathrm{wR} 2$ relative to $\mathrm{N} 2$ & $0.0771 / 0.1189$ \\
\hline $\mathrm{S}$ & 0.89 \\
\hline$\Delta \rho_{\max } / \Delta \rho_{\min }, \mathrm{e} / \AA^{3}$ & $0.624 /-0.498$ \\
\hline Program package & Sadabs [10], SHELXTL [11] \\
\hline
\end{tabular}


Table 2. Selected bond angles for $\mathrm{C}_{44} \mathrm{H}_{61} \mathrm{BrN}_{4} \mathrm{O}_{8}(\mathbf{1})$.

\begin{tabular}{|c|c|c|c|c|c|c|c|}
\hline Bond & d & Bond & $\mathrm{d}$ & Bond & d & Bond & d \\
\hline $\mathrm{O} 1-\mathrm{C} 7$ & $1.377(2)$ & C7-C12 & $1.369(3)$ & C1-H1A & 0.9700 & $\mathrm{C} 15-\mathrm{C} 20$ & $1.372(3)$ \\
\hline O1-C6 & $1.417(2)$ & C7-C8 & $1.374(3)$ & C1-H1B & 0.9700 & $\mathrm{C} 16-\mathrm{C} 17$ & $1.376(3)$ \\
\hline $\mathrm{O} 2-\mathrm{C} 10$ & $1.367(2)$ & C8-C9 & $1.369(3)$ & $\mathrm{C} 2-\mathrm{C} 3$ & $1.508(3)$ & C16-H16A & 0.9300 \\
\hline $\mathrm{O} 2-\mathrm{C} 22$ & $1.402(3)$ & C8-H8A & 0.9300 & $\mathrm{C} 2-\mathrm{H} 2 \mathrm{~A}$ & 0.9700 & C17-C18 & $1.378(3)$ \\
\hline O3-C15 & $1.378(2)$ & C9-C10 & $1.381(3)$ & $\mathrm{C} 2-\mathrm{H} 2 \mathrm{~B}$ & 0.9700 & C17-H17A & 0.9300 \\
\hline $\mathrm{O} 3-\mathrm{C} 14$ & $1.409(3)$ & C9-H9A & 0.9300 & $\mathrm{C} 3-\mathrm{H} 3 \mathrm{~A}$ & 0.9700 & C18-C19 & $1.364(3)$ \\
\hline $\mathrm{O} 4-\mathrm{C} 18$ & $1.374(2)$ & $\mathrm{C} 10-\mathrm{C} 11$ & $1.367(3)$ & C3-H3B & 0.9700 & C19-C20 & $1.391(3)$ \\
\hline $\mathrm{O} 4-\mathrm{C} 21$ & $1.409(3)$ & C11-C12 & $1.389(3)$ & $\mathrm{C} 4-\mathrm{N} 2 \mathrm{i}$ & $1.465(2)$ & C19-H19A & 0.9300 \\
\hline N1-C2 & $1.475(2)$ & C11-H11A & 0.9300 & $\mathrm{C} 4-\mathrm{H} 4 \mathrm{~A}$ & 0.9700 & C20-H20A & 0.9300 \\
\hline N1-C1 & $1.476(2)$ & C12-H12A & 0.9300 & C4-H4B & 0.9700 & $\mathrm{C} 21-\mathrm{H} 21 \mathrm{~A}$ & 0.9600 \\
\hline N1-C5 & $1.478(3)$ & $\mathrm{C} 13-\mathrm{C} 14$ & $1.510(3)$ & C5-C6 & $1.501(3)$ & $\mathrm{C} 21-\mathrm{H} 21 \mathrm{~B}$ & 0.9600 \\
\hline N1-H33 & 0.9178 & C13-H13A & 0.9700 & C5-H5A & 0.9700 & $\mathrm{C} 21-\mathrm{H} 21 \mathrm{C}$ & 0.9600 \\
\hline N2-C3 & $1.448(3)$ & C13-H13B & 0.9700 & C5-H5B & 0.9700 & $\mathrm{C} 22-\mathrm{H} 22 \mathrm{~A}$ & 0.9600 \\
\hline $\mathrm{N} 2-\mathrm{C} 4^{\mathrm{i}}$ & $1.465(2)$ & C14-H14A & 0.9700 & C6-H6A & 0.9700 & $\mathrm{C} 22-\mathrm{H} 22 \mathrm{~B}$ & 0.9600 \\
\hline $\mathrm{N} 2-\mathrm{C} 13$ & $1.467(2)$ & C14-H14B & 0.9700 & C6-H6B & 0.9700 & $\mathrm{C} 22-\mathrm{H} 22 \mathrm{C}$ & 0.9600 \\
\hline
\end{tabular}

Symmetry transformations used to generate equivalent atoms: $-x+1, y,-z+3 / 2$.

$0.2 \mathrm{~mm} \times 0.2 \mathrm{~mm}$ ) was selected for data collection which was performed on a Bruker Apex II CCD diffractmeter equipped with a graphite-monochromatic CuKa radiation $(\lambda=0.71073 \mathrm{~nm})$ at $293(2) \mathrm{K}$. A total of 24,759 reflections were collected in the range of $1.96 \leq \theta \leq 28.08^{\circ}(-22 \leq \mathrm{h} \leq 22,-16 \leq \mathrm{k} \leq 6$ and $-25 \leq 1 \leq$ 24 ), of which 24,759 were unique with $R_{\text {int }}=0.1233$ and 5200 were observed with $\mathrm{I}>2 \sigma(\mathrm{I})$. Corrections for LP factors and semi-empirical absorption were applied based on Sadabs [15]. Unique data (Rint $=0.1233$ ) were used to solve the structure by direct methods with SHELXS-97 program [16]. Most non-hydrogen atoms were determined with an E-map and the others were located in successive difference Fourier syntheses. Then, the final refinement was carried out by full-matrix least-squares methods with anisotropic thermal parameters for the non-hydrogen atoms on $\mathrm{F}^{2}$. The hydrogen atoms were located theoretically and refined with riding model position parameters and fixed isotropic thermal parameters. A full-matrix least-squares refinement gave the final $\mathrm{R}=0.0434, \mathrm{wR}=$ $0.1091\left(\mathrm{w}=1 /\left[\sigma^{2}\left(\mathrm{Fo}^{2}\right)+(0.20 \mathrm{P})^{2}+0.00 \mathrm{P}\right]\right.$, where $\left.\mathrm{P}=\left(\mathrm{Fo}^{2}+2 \mathrm{Fc}^{2}\right) / 3\right), \mathrm{S}=0.89$, $(\Delta / \sigma)_{\max }=0.00,(\Delta \rho)_{\max }=0.624$ and $(\Delta \rho)_{\min }=-0.498 \mathrm{e} / \AA^{3}$. The CIF file containing complete information on the studied structure was deposited with CCDC, deposition number $1,403,270$, and is freely available upon request from the following web site: http://www.ccdc.cam.ac.uk/data_request/cif, and also available from the authors.

\section{Results and Discussion}

We describe herein the structure of the title compound 1 which is stable in air at room temperature. It is soluble in methanol and ethanol at higher temperature 
and soluble in $\mathrm{CH}_{2} \mathrm{Cl}_{2}$ and $\mathrm{CHCl}_{3}$. X-ray quality crystals of 1 were grown from ethanol by slow evaporation at room temperature for several days. The molecular structure of 1 crystallizes in orthorhombic space group Pbcn. Molecular structure of 1 is shown in Figure 1.

$\mathrm{X}$-ray single-crystal structural analysis revealed that all the bond lengths and bond angles in the compound are within normal ranges and comparable to those corresponding in other similar compounds (Table 2 and Table S1). As shown in Figure 1, the asymmetric unit of 1 contains one half of organic cation, because it is situated on twofold axis. All the four hydroquinone groups of the benzene ring deviate in the same direction. They converge to form the resemblance of a binding $\pi$-electron-rich cavity. The depth of the cavity measured from the plane of $\mathrm{O}(1)$ and $\mathrm{O}(3)$ to the uppermost aromatic oxygen atom is $5.7 \AA$. The diameter of the cavity, defined as the shortest separation between the ring centroids of the three phenyl rings, is calculated to be $4.5 \AA$. There is no evidence for $\pi \cdots \pi$ interactions between the phenyl ring and another phenyl ring with their shortest separation larger than $4 \AA$. Similarly, Timothy S. R. et al. [17] also reported the defined boundaries of the $\pi$-electron-rich cavity via $\mathrm{C}-\mathrm{H} \cdots \pi$ stacking interactions, and commented on the cyclen derivatives, including four phenoxymethyl groups.

Hydrogen bonding interactions are usually important in the synthesis of supramolecular architecture [18]. In addition to the aromatic interactions, there are intermolecular $\mathrm{C}-\mathrm{H} \cdots \mathrm{O}$ hydrogen bonding interactions between the $\mathrm{C}(9)-\mathrm{H}(9 \mathrm{~A})$ and $\mathrm{C}(17)-\mathrm{H}(17 \mathrm{~A})$ groups from benzyl groups carbon atoms $(\mathrm{C}(7)$ to $\mathrm{C}(12)$ and $\mathrm{C}(15)$ to $\mathrm{C}(20)$ ) and $\mathrm{O}(2)$ and $\mathrm{O}(4)$ from methoxyl, resulting in an extended two-dimensional structure. But there are not intermolecular $\mathrm{C}-\mathrm{H} \cdots \mathrm{O}$ hydrogen bonding interactions between $(\mathrm{O}(1)$ and $\mathrm{O}(3))$ and benzyl groups carbon atoms (Figure 2). As shown in Figure 2, there are intramolecular $\mathrm{C}-\mathrm{H} \cdots \mathrm{Br}$ hydrogen bonding interactions between the $(\mathrm{C}(2)-\mathrm{H}(2 \mathrm{~A})$, and

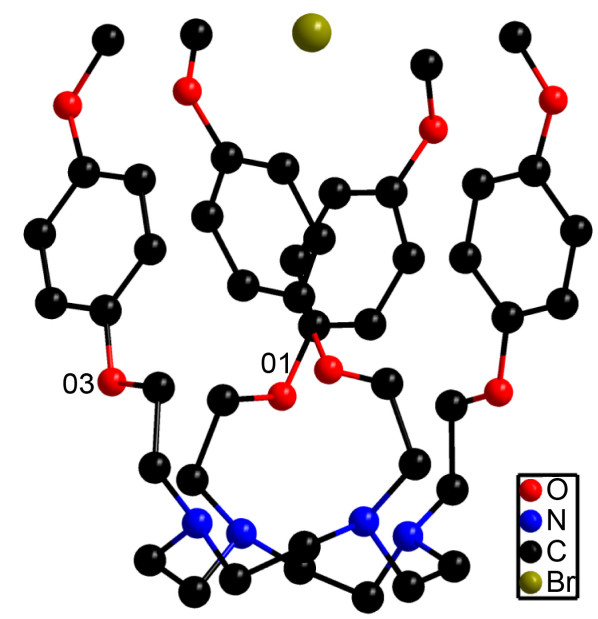

Figure 1. Molecular structure of 1 . All hydrogen atoms are omitted from the figure for clarity. 
$\mathrm{C}(4)-\mathrm{H}(4 \mathrm{~A}))$ from cyclen ring carbon atom $(\mathrm{C}(1)$ to $\mathrm{C}(8))$ and $(\mathrm{C}(11)-\mathrm{H}(11 \mathrm{~A})$ and $\mathrm{C}(21)-\mathrm{H}(21 \mathrm{~A}))$ and $\mathrm{Br}(1)$. A three-dimensional structure is formed through these weak interactions among molecules. The molecules hydrogen bromides serve as the donor to carbon atoms, giving a total of crystallographically unique hydrogen bonds for 1 .

The packing diagram is shown in Figure 3, where four molecules exist in the unit cell. The four molecules have a centrosymmetric distribution with the centroid of the unit cell. This assignment is favorable to crystal packing. There are two enantiomorphism crystals in the crystal packing diagram of 1. (A and D), (B and $\mathrm{E}$ ) and (C and F) are mirror-related with each other (Figure 4).
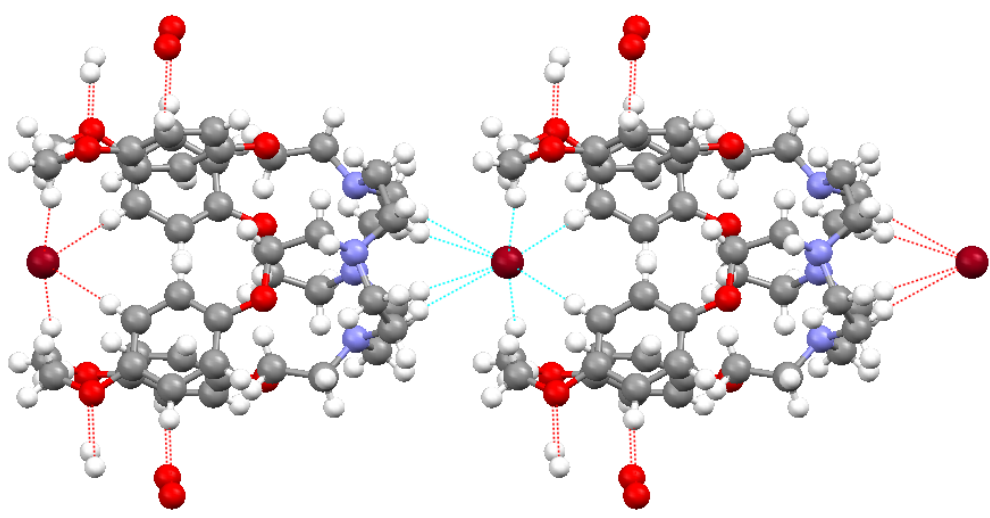

Figure 2. Dimolecular graph of 1 . All hydrogen atoms are omitted for clarity. Intramolecular $\mathrm{C}-\mathrm{H} \cdots \mathrm{Br}$ and $\mathrm{C}-\mathrm{H} \cdots \mathrm{O}$ hydrogen bonds are shown as dashed lines.

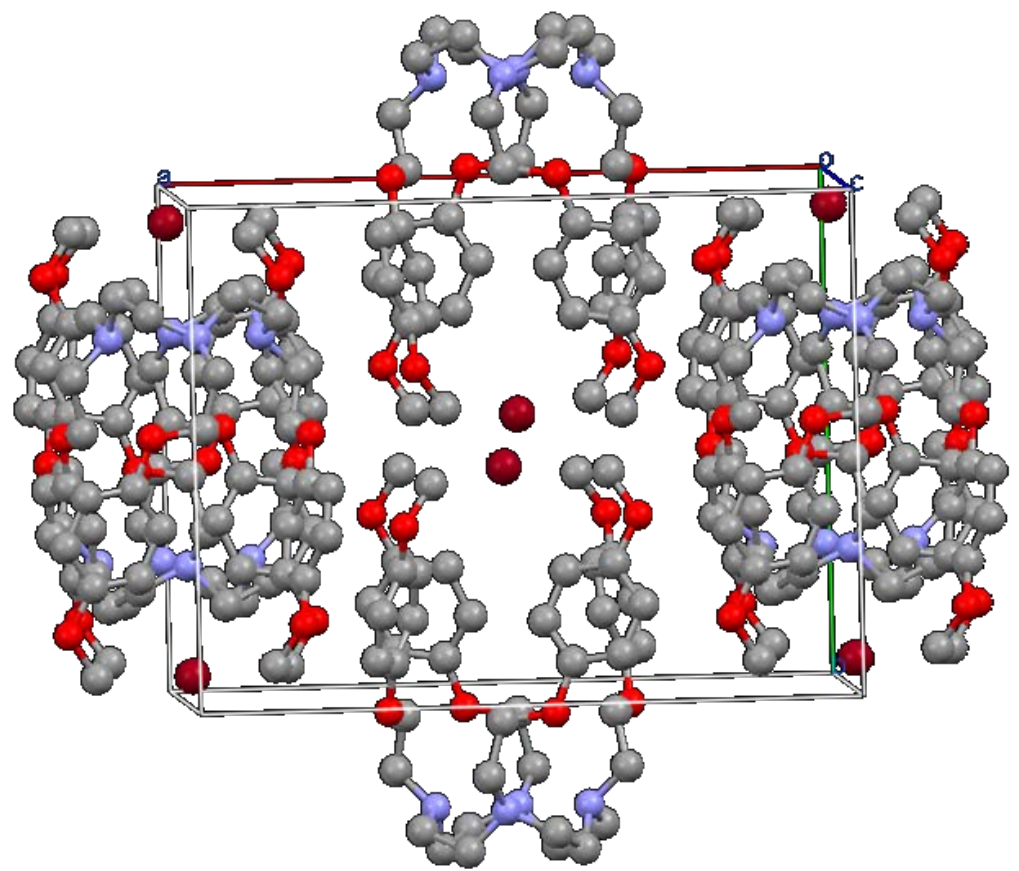

Figure 3. Crystal packing diagram of 1. Hydrogen atoms are omitted for clarity. 


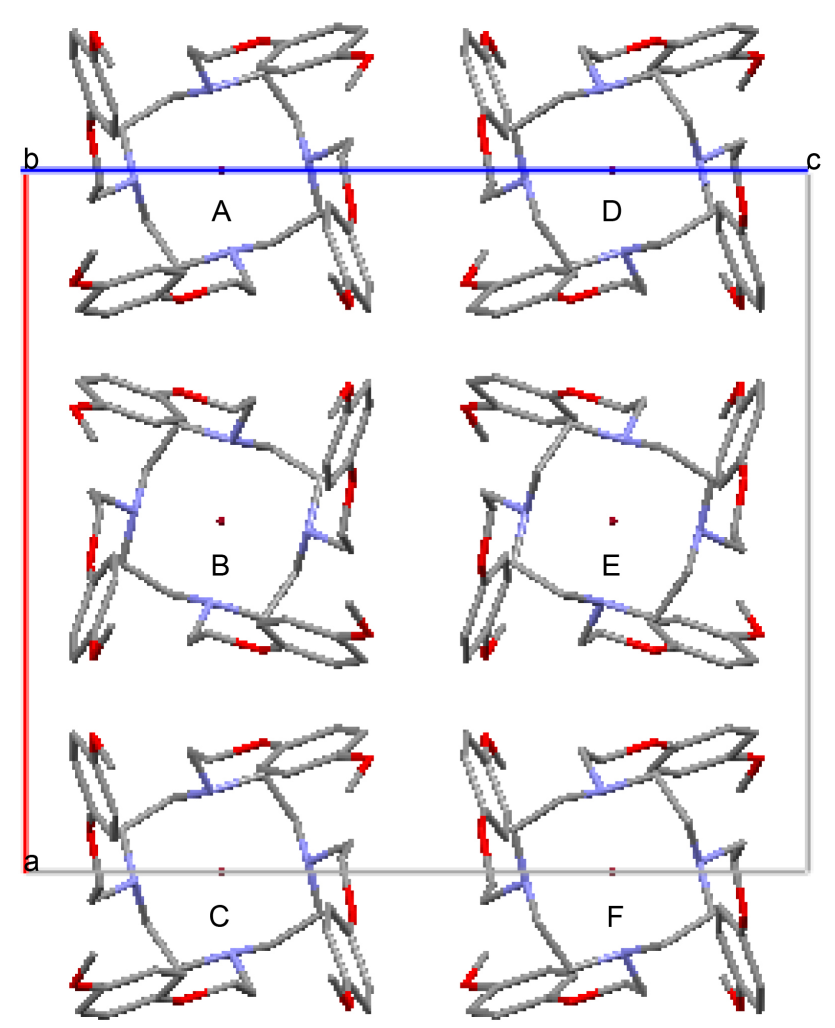

Figure 4. Crystal packing diagram of 1 in the unit cell along b.

\section{Conclusion}

In summary, this efficient one-step synthesis has yielded a novel molecule 1,4,7,10-tetrakis(2-((4-methoxy)phenoxy)ethyl)-1,4,7,10-tetraazacyclododecane 1. The cyclen derivatives contain four hydroquinone units carrying ethylene chains. All the four hydroquinone groups form a $\pi$-electron-rich cavity. This cavity-like structure of cyclen derivatives is expected to present interesting properties. Indeed, the reported cyclen derivatives bearing four hydroquinone moieties may play a significant role towards the improvement in metal coordination or small molecule induced by the reinforced cycles, due to the formation of the cavity-like structure. However, this work is poor in coordinating with metal ion or small molecule. These features are currently underway.

\section{Acknowledgements}

This research was supported financially by the National Natural Science Foundation of China (51506077), the Natural Science Foundation of Jiangsu Province (BK20150488), the Natural Science Foundation of Jiangsu High School (15KJB430007, 15KJB610003, 15KJD150002), the China Postdoctoral Foundation (2016M601733) and Research Foundation of Jiangsu University (13JDG066, 15JDG156).

\section{References}

[1] Yang, Q., Xu, J.Q., Sun, Y.S., Li, Z.G., Li, Y.G. and Q, X.H. (2006) Hydrolysis of 
Plasmid DNA and RNA by Amino Alkyl Naphthalimide as Metal-Free Artificial Nuclease. Bioorganic \& Medicinal Chemistry Letters, 16, 803-806. https://doi.org/10.1016/j.bmcl.2005.11.020

[2] Huang, J.M., Chen, R.Y., Chen, H. and Wang, H.G. (2001) Crystal and Molecular Structure of N-(1-Ethoxycarbonyl-ethyl)1-Ethoxycarbonylmethyl-3-ethyl-1,2,3,4tetrahydro-4-oxo-2,3,2-benzodiazaphosphorin-2-carboxamide 2-Oxide. Chinese Journal of Structural Chemistry, 5, 349-353.

[3] Wu, H.C., Du, D.M., Hua, W.T. and Jin, X.L. (2003) Synthesis and Crystal Structure of the Novel Chiral o-Hydroxyphenyloxazoline Metal Complexes. Chinese Journal of Structural Chemistry, 2, 155-160.

[4] Cheng, F.F., Zhang, J.J., Xu, F., Hu, L.H., Abdel-Halim, E.S. and Zhu, J.J. (2013) pH-Sensitive Polydopamine Nanocapsules for Cell Imaging and Drug Delivery Based on Folate Receptor Targetting. Journal of Biomedical Nanotechnology, 9, 1155-1163. https://doi.org/10.1166/jbn.2013.1611

[5] Zhou, S.W., Zheng, T.T., Chen, Y.F., Zhang, J.J., Li, T.T., Li, F. and Zhu, J.J. (2014) Toward Therapeutic Effects of Chronic Myeloid Leukemia Drug: Electrochemical Platform for Caspase-3 Activity Sensing. Biosensors and Bioelectronics, 61, 648-654. https://doi.org/10.1016/j.bios.2014.05.064

[6] Zhang, J.J., Cheng, F.F., Li, J.J., Zhu, J.J. and Lu, Y. (2016) Fluorescent Nanoprobes for Sensing and Imaging of Metal Ions: Recent Advances and Future Perspectives. Nanotoday, 11, 309-329. https://doi.org/10.1016/j.nantod.2016.05.010

[7] Kim, M.S. and Suh, J.H. (2005) Immobile Artificial Metalloproteases. Bulletin-Korean Chemistry Society, 26, 1911-1913. https://doi.org/10.5012/bkcs.2005.26.12.1911

[8] Fang, Y.G., Zhang, J., Chen, S.Y., Jiang, N., Lin, H.H., Zhang, Y. and Yu, X.Q. (2007) Chiral Multinuclear Macrocyclic Polyamine Complexes: Synthesis, Characterization and Their Interaction with Plasmid DNA. Bioorganic \& Medicinal Chemistry, 15, 696-701. https://doi.org/10.1016/j.bmc.2006.10.057

[9] Wang, X.Y., Zhang, J., Li, K., Jiang, N., Chen, S.Y., Lin, H.H., Huang, Y. Li, J.M. and Yu, X.Q. (2006) Synthesis and DNA Cleavage Activities of Mononuclear Macrocyclic Polyamine Zinc(II), Copper(II), Cobalt(II) Complexes Which Linked with Uracil. Bioorganic \& Medicinal Chemistry, 14, 6745-6751. https://doi.org/10.1016/j.bmc.2006.05.049

[10] Wardle, N.L., Herlihy, A.H., So, P.W., Bell, J.D. and Bligh, S.W.A. (2007) Synthesis of a Novel 'Smart' Bifunctional Chelating Agent 1-(2-[ $\beta, d-G a l a c t o p y r a n o s y l o x y]$ ethyl)-7-(1-carboxy-3-[4-aminophenyl]propyl)-4,10-bis(carboxymethyl)-1,4,7,10-te traazacyclododecane (Gal-PA-DO3A-NH2) and Its Gd(III) Complex. Bioorganic \& Medicinal Chemistry, 15, 4714-4721. https://doi.org/10.1016/j.bmc.2007.05.004

[11] Woods, M., Kiefer, G.E., Bott, S., Muzquiz, A.C., Eshelbrebber, C., Michaudet, L., McMillan, K., Mudigunda, S.D.K., Ogrin, D., Zhang, S.R., Zhao, P.Y. and Sherry, D. (2004) Synthesis, Relaxometric and Photophysical Properties of a New pH-Responsive MRI Contrast Agent: The Effect of Other Ligating Groups on Dissociation of a p-Nitrophenolic Pendant Arm. Journal of the American Chemical Society, 126, 9248-9256. https://doi.org/10.1021/ja048299z

[12] Shinada, S. (2013) Dynamic Cyclen-Metal Complexes for Molecular Sensing and Chirality Signaling. Chemical Society Reviews, 42, 1825-1835.

https://doi.org/10.1039/C2CS35295H

[13] Smith, C.B., Buntine, M.A., Lincoln, S.F. and Wainwright, K.P. (2003) Metal IonActivated Molecular Receptors for Aromatic Anions with Receptor Cavities Formed from 1- or 2-Naphthyloxy Moieties Appended to Cyclen. Dalton Transactions, 2003, 3028-3033. https://doi.org/10.1039/b305461f 
[14] Bruker, A., Saint, P. and Sadabs, B. (2004) BrukerAXS. Madison, USA.

[15] Sheldrick, G.M. (1997) SHELXL-97: Program for the Refinement of Crystal Structures. University of Göttingen, Germany.

[16] Wright and Wright, W. (1906) Flying-Machine. US Patent No. 821393.

[17] Robinson, T.S., Wyness, O., Lincoln, S.F., Taylor, M.R., Tiekink, E.R.T. and Wainwright, K.P. (2006) A Structural Study of the Synergic Envelopment of Acetonitrile by a Cd(II) Activated Molecular Receptor Formed from Cyclen with Appended 2-Hydroxy-3-phenylpropyl Moieties. Inorganica Chimica Acta, 359, 1413-1420. https://doi.org/10.1016/j.ica.2005.09.018

[18] Zhang, L.N., Shi, L., Fang, R.Q. and Zhu, H.L. (2008) Synthesis and Crystal Structure of a Genistein-derived Compound. Chinese Journal of Structural Chemistry, 2, 200-204. 


\section{Appendix}

Table S1. Selected bond angles for $\mathrm{C}_{44} \mathrm{H}_{61} \mathrm{BrN}_{4} \mathrm{O}_{8}(\mathbf{1})$.

\begin{tabular}{|c|c|c|c|}
\hline $\mathrm{C} 7-\mathrm{O} 1-\mathrm{C} 6$ & $116.70(16)$ & $\mathrm{C} 8-\mathrm{C} 9-\mathrm{C} 10$ & $120.41(19)$ \\
\hline $\mathrm{C} 10-\mathrm{O} 2-\mathrm{C} 22$ & $117.31(18)$ & $\mathrm{C} 8-\mathrm{C} 9-\mathrm{H} 9 \mathrm{~A}$ & 119.800 \\
\hline $\mathrm{C} 15-\mathrm{O} 3-\mathrm{C} 14$ & $116.58(15)$ & $\mathrm{C} 10-\mathrm{C} 9-\mathrm{H} 9 \mathrm{~A}$ & 119.800 \\
\hline $\mathrm{C} 18-\mathrm{O} 4-\mathrm{C} 21$ & $116.75(17)$ & $\mathrm{C} 11-\mathrm{C} 10-\mathrm{O} 2$ & 124.91(19) \\
\hline $\mathrm{C} 2-\mathrm{N} 1-\mathrm{C} 1$ & $111.25(16)$ & $\mathrm{C} 11-\mathrm{C} 10-\mathrm{C} 9$ & $119.5(2)$ \\
\hline $\mathrm{C} 2-\mathrm{N} 1-\mathrm{C} 5$ & $110.35(16)$ & $\mathrm{O} 2-\mathrm{C} 10-\mathrm{C} 9$ & $115.61(19)$ \\
\hline $\mathrm{C} 1-\mathrm{N} 1-\mathrm{C} 5$ & $111.67(16)$ & $\mathrm{C} 10-\mathrm{C} 11-\mathrm{C} 12$ & $119.94(19)$ \\
\hline $\mathrm{C} 2-\mathrm{N} 1-\mathrm{H} 33$ & 109.400 & $\mathrm{C} 10-\mathrm{C} 11-\mathrm{H} 11 \mathrm{~A}$ & 120.000 \\
\hline $\mathrm{C} 1-\mathrm{N} 1-\mathrm{H} 33$ & 100.600 & $\mathrm{C} 12-\mathrm{C} 11-\mathrm{H} 11 \mathrm{~A}$ & 120.000 \\
\hline $\mathrm{C} 5-\mathrm{N} 1-\mathrm{H} 33$ & 113.200 & $\mathrm{C} 7-\mathrm{C} 12-\mathrm{C} 11$ & $120.29(18)$ \\
\hline $\mathrm{C} 3-\mathrm{N} 2-\mathrm{C} 4^{\mathrm{i}}$ & $111.30(16)$ & $\mathrm{C} 7-\mathrm{C} 12-\mathrm{H} 12 \mathrm{~A}$ & 119.900 \\
\hline $\mathrm{C} 3-\mathrm{N} 2-\mathrm{C} 13$ & $112.46(17)$ & $\mathrm{C} 11-\mathrm{C} 12-\mathrm{H} 12 \mathrm{~A}$ & 119.900 \\
\hline $\mathrm{C} 4 \mathrm{i}-\mathrm{N} 2-\mathrm{C} 13$ & $110.85(16)$ & $\mathrm{N} 2-\mathrm{C} 13-\mathrm{C} 14$ & $113.04(18)$ \\
\hline $\mathrm{N} 1-\mathrm{C} 1-\mathrm{C} 4$ & $113.15(16)$ & $\mathrm{N} 2-\mathrm{C} 13-\mathrm{H} 13 \mathrm{~A}$ & 109.000 \\
\hline $\mathrm{N} 1-\mathrm{C} 1-\mathrm{H} 1 \mathrm{~A}$ & 108.900 & $\mathrm{C} 14-\mathrm{C} 13-\mathrm{H} 13 \mathrm{~A}$ & 109.000 \\
\hline $\mathrm{C} 4-\mathrm{C} 1-\mathrm{H} 1 \mathrm{~A}$ & 108.900 & $\mathrm{~N} 2-\mathrm{C} 13-\mathrm{H} 13 \mathrm{~B}$ & 109.000 \\
\hline $\mathrm{N} 1-\mathrm{C} 1-\mathrm{H} 1 \mathrm{~B}$ & 108.900 & $\mathrm{C} 14-\mathrm{C} 13-\mathrm{H} 13 \mathrm{~B}$ & 109.000 \\
\hline $\mathrm{C} 4-\mathrm{C} 1-\mathrm{H} 1 \mathrm{~B}$ & 108.900 & $\mathrm{H} 13 \mathrm{~A}-\mathrm{C} 13-\mathrm{H} 13 \mathrm{~B}$ & 107.800 \\
\hline $\mathrm{H} 1 \mathrm{~A}-\mathrm{C} 1-\mathrm{H} 1 \mathrm{~B}$ & 107.800 & $\mathrm{O} 3-\mathrm{C} 14-\mathrm{C} 13$ & $109.86(19)$ \\
\hline $\mathrm{N} 1-\mathrm{C} 2-\mathrm{C} 3$ & $112.38(17)$ & $\mathrm{O} 3-\mathrm{C} 14-\mathrm{H} 14 \mathrm{~A}$ & 109.700 \\
\hline $\mathrm{N} 1-\mathrm{C} 2-\mathrm{H} 2 \mathrm{~A}$ & 109.100 & $\mathrm{C} 13-\mathrm{C} 14-\mathrm{H} 14 \mathrm{~A}$ & 109.700 \\
\hline $\mathrm{C} 3-\mathrm{C} 2-\mathrm{H} 2 \mathrm{~A}$ & 109.100 & $\mathrm{O} 3-\mathrm{C} 14-\mathrm{H} 14 \mathrm{~B}$ & 109.700 \\
\hline $\mathrm{N} 1-\mathrm{C} 2-\mathrm{H} 2 \mathrm{~B}$ & 109.100 & $\mathrm{C} 13-\mathrm{C} 14-\mathrm{H} 14 \mathrm{~B}$ & 109.700 \\
\hline $\mathrm{C} 3-\mathrm{C} 2-\mathrm{H} 2 \mathrm{~B}$ & 109.100 & $\mathrm{H} 14 \mathrm{~A}-\mathrm{C} 14-\mathrm{H} 14 \mathrm{~B}$ & 108.200 \\
\hline $\mathrm{H} 2 \mathrm{~A}-\mathrm{C} 2-\mathrm{H} 2 \mathrm{~B}$ & 107.900 & $\mathrm{C} 16-\mathrm{C} 15-\mathrm{C} 20$ & $119.48(18)$ \\
\hline $\mathrm{N} 2-\mathrm{C} 3-\mathrm{C} 2$ & $113.48(16)$ & $\mathrm{C} 16-\mathrm{C} 15-\mathrm{O} 3$ & $116.04(17)$ \\
\hline $\mathrm{N} 2-\mathrm{C} 3-\mathrm{H} 3 \mathrm{~A}$ & 108.900 & $\mathrm{C} 20-\mathrm{C} 15-\mathrm{O} 3$ & $124.47(18)$ \\
\hline $\mathrm{C} 2-\mathrm{C} 3-\mathrm{H} 3 \mathrm{~A}$ & 108.900 & $\mathrm{C} 15-\mathrm{C} 16-\mathrm{C} 17$ & $120.64(18)$ \\
\hline $\mathrm{N} 2-\mathrm{C} 3-\mathrm{H} 3 \mathrm{~B}$ & 108.900 & $\mathrm{C} 15-\mathrm{C} 16-\mathrm{H} 16 \mathrm{~A}$ & 119.700 \\
\hline $\mathrm{C} 2-\mathrm{C} 3-\mathrm{H} 3 \mathrm{~B}$ & 108.900 & $\mathrm{C} 17-\mathrm{C} 16-\mathrm{H} 16 \mathrm{~A}$ & 119.700 \\
\hline $\mathrm{H} 3 \mathrm{~A}-\mathrm{C} 3-\mathrm{H} 3 \mathrm{~B}$ & 107.700 & $\mathrm{C} 16-\mathrm{C} 17-\mathrm{C} 18$ & $119.86(18)$ \\
\hline $\mathrm{N} 22^{\mathrm{i}}-\mathrm{C} 4-\mathrm{C} 1$ & $112.45(16)$ & $\mathrm{C} 16-\mathrm{C} 17-\mathrm{H} 17 \mathrm{~A}$ & 120.100 \\
\hline $\mathrm{N} 2^{\mathrm{i}}-\mathrm{C} 4-\mathrm{H} 4 \mathrm{~A}$ & 109.100 & $\mathrm{C} 18-\mathrm{C} 17-\mathrm{H} 17 \mathrm{~A}$ & 120.100 \\
\hline $\mathrm{C} 1-\mathrm{C} 4-\mathrm{H} 4 \mathrm{~A}$ & 109.100 & $\mathrm{C} 19-\mathrm{C} 18-\mathrm{O} 4$ & $124.42(18)$ \\
\hline $\mathrm{N} 2^{\mathrm{i}}-\mathrm{C} 4-\mathrm{H} 4 \mathrm{~B}$ & 109.100 & $\mathrm{C} 19-\mathrm{C} 18-\mathrm{C} 17$ & $119.97(19)$ \\
\hline $\mathrm{C} 1-\mathrm{C} 4-\mathrm{H} 4 \mathrm{~B}$ & 109.100 & $\mathrm{O} 4-\mathrm{C} 18-\mathrm{C} 17$ & $115.61(17)$ \\
\hline $\mathrm{H} 4 \mathrm{~A}-\mathrm{C} 4-\mathrm{H} 4 \mathrm{~B}$ & 107.800 & $\mathrm{C} 18-\mathrm{C} 19-\mathrm{C} 20$ & $119.82(18)$ \\
\hline $\mathrm{N} 1-\mathrm{C} 5-\mathrm{C} 6$ & $113.9(2)$ & $\mathrm{C} 18-\mathrm{C} 19-\mathrm{H} 19 \mathrm{~A}$ & 120.100 \\
\hline $\mathrm{N} 1-\mathrm{C} 5-\mathrm{H} 5 \mathrm{~A}$ & 108.800 & $\mathrm{C} 20-\mathrm{C} 19-\mathrm{H} 19 \mathrm{~A}$ & 120.100 \\
\hline
\end{tabular}




\section{Continued}

\begin{tabular}{cccc}
\hline C6-C5-H5A & 108.800 & C15-C20-C19 & $120.20(19)$ \\
N1-C5-H5B & 108.800 & C15-C20-H20A & 119.900 \\
C6-C5-H5B & 108.800 & C19-C20-H20A & 119.900 \\
H5A-C5-H5B & 107.700 & O4-C21-H21A & 109.500 \\
O1-C6-C5 & $109.71(19)$ & O4-C21-H21B & 109.500 \\
O1-C6-H6A & 109.700 & H21A-C21-H21B & 109.500 \\
C5-C6-H6A & 109.700 & O4-C21-H21C & 109.500 \\
O1-C6-H6B & 109.700 & H21A-C21-H21C & 109.500 \\
C5-C6-H6B & 109.700 & $\mathrm{H} 21 B-C 21-H 21 C$ & 109.500 \\
H6A-C6-H6B & 108.200 & O2-C22-H22A & 109.500 \\
C12-C7-C8 & $119.56(18)$ & O2-C22-H22B & 109.500 \\
C12-C7-O1 & $125.43(18)$ & H22A-C22-H22B & 109.500 \\
C8-C7-O1 & $114.98(17)$ & O2-C22-H22C & 109.500 \\
C9-C8-C7 & $120.32(19)$ & H22A-C22-H22C & 109.500 \\
C9-C8-H8A & 119.800 & H22B-C22-H22C & 109.500 \\
C7-C8-H8A & 119.800 & & \\
\hline
\end{tabular}

